Marble, A. (1932). Amer. 7. med. Sci., 183, 811.

Marsden, H. B., and Wilson, V. K. (1955). Brit. med. F., 1, 324

Mayrs, B. B. (1923). 7. Physiol. (Lond.), 57, 461.

Menkes, J. H., Hurst, P. L., and Craig, J. M. (1954). Pediatrics, 14, 462.

Milne, M. D., Asatoor, A. M., Edwards, K. D. G., and Loughridge, L. W. (1961). Gut, 2, 323.

- Crawford, M. A., Girão, C. B., and Loughridge, L. (1959). Błochem. F., 72, 30P.

- - (1960). Quart. f. Med., 29, 407.

- and de Rousse, A. R. (1963). Unpublished observations.

Patrick, A. D. (1962). Biochem. Ү., 83, 248.

Pihl, A., Eldjarn, L., and Nakkem, K. F. (1958). Act. chem. scand., 12, 1357.

Poulsson, L. T. (1930). 7. Physiol. (Lond.), 69, 411.

Reubi, F. C. (1951). Helv. med. Acta, 18, 69.

Robson, E. B., and Rose, G. A. (1957). Clin. Sci., 16, 75.

Rothstein, A., and Berke, H. (1949). F. Pharmacol. exp. Ther., 96, 179.

Royer, P., and Prader, A. (1957). 16e Congrís des Pediatres de Langue Française, June 1, 263. Expansion Scientifique Française, Paris.

Ruszkowski, M., Baertl, J. M., and Gabuzda, G. J. (1960). Pol. Tyg. lek., $15,1679$.

Ryle, A. P., and Sanger, F. (1955). Biochem. 7., 60, 535.

Schafer, I. A., Scriver, C. R., and Efron, M. L. (1962). New Engl. \}. Med., 267, 51.

Schwarz-Tiene, E., Careddu, P., and Labassa, N. (1957). Minerva pediat., 9, 231.

Scowen, E. F., and Crawhall, J. C. (1963). Brit. med. f., 2, 250.

Scriver, C. R., Schafer, I. A., and Efron, M. L. (1961). Nature (Lond.), 192, 672.

Seegmiller, J. E., and Howell, R. R. (1961). Clin. Res., 9, 189.

Shaw, K. N. F., Redlich, D., Wright, S. W., and Jepson, J. B. (1960). Fed. Proc., 19, 194.

Sherlock, S. (1958). Amor. f. Med, 24, 805

Sirota, J. H., and Hamerman, D. J. (1954). Ibid., 16, 138.
Spencer, A. G., and Franglen, G. T. (1952). Lancet, 1, 190.

Stanbury, S. W (1958). Advanc. intern. Med., 9, 231.

Stanbury, (1962). Renal Disease, edited by D. A. K. Black. Blackwell, Oxford.

and Macaulay, D. (1957). Quart. F. Med., 26, 7.

Stave, U., and Schlaak, E. (1956). Z. Kinderheilk., 78, 261.

Stave, U., and Willenbockel, U. (1956). Ibid., 78, 563.

Sunderman. F. W., jun., White, J. C., and Sunderman, F. W. (1963). Amer. 7. Med., 34, 875.

Tegelaers, W. H. H., and Tiddens, H. W. (1955). Helv. paediat. Acta, 10, 269.

Treacher, R. J. (1962). Vet. Rec., 74, 503.

- (1963). Personal communication.

von Mering, I. (1888). Z. klin. Med., 14, 405

Walshe, J. M. (1953). Quart. F. Med., 22, 483.

- (1956). Amer. F. Med., 21, 487.

(1961). Clin. Sci., 20, 197

Webber, W. A. (1963). Canad. F. Biochem., 41, 131.

Brown, J. L., and Pitts, R. F. (1961). Amer. f. Physiol., 200, 380.

Weyers, H., and Bickel, H. (1958). Klin. Wschr., 36, 893.

Wileon, T. H. (1962). Intestinal Absorption. Saunders, Philadelphia.

Wiseman, G. (1954a). F. Physiol. (Lond.), 123, 116.

Wilson, V. K., Thomson, M. L., and Dent, C. E. (1953). Lancet, 2, 66.

Wiseman, G. (1953). 7. Physiol. (Lond.), 120, 63.

- (1955). Ibid., 127, 414.

- (1961). Methods in Medical Research, edited by J. H. Quastel, 9, 287. Year Book Medical Publishers, Chicago.

Wolff, S. M. (1962). Clin. Res., 10. 45.

Wollaston, W. H. (1810). Philos. Trans., 100, 223.

Worthen, H. G., and Good, R. A. (1958). Amer. 7. Dis. Child., 95, 653. - (1961). Ibnd., 102, 494.

Wrong, O., and Davies, H. E. F. (1959). Quart. F. Med., 28, 259.

Yonis, I. Z., and Karp, M. (1963). Lancet, 2, 689.

\title{
Cancer in an African Community, 1897-1956*
}

\section{An Analysis of the Records of Mengo Hospital, Kampala, Uganda : Part 2}

\author{
J. N. P. DAVIES, † § M.D. ; SALLY ELMES†; M. S. R. HUTT, $\ddagger$ M.D., M.R.C.P. ; L. A. R. MTIMAVALYE \\ R. OWOR, $\ddagger$ L.M.S. ; LORNA SHAPER
}

Brit. med. F., 1964, 1, 336-341

\section{Cancer at Special Sites}

\section{Oro-Facial Region}

Lip cancer probably represents the only genuine change in the cancer pattern disclosed by these records. It seems to have declined steadily over the six decades until to-day it is an uncommon tumour. In the Mengo series there were 11 females and 5 males; in the Registry series 4 females and 4 males. All 16 Mengo patients were elderly ; in 15 the lower lip or angle of the mouth was affected, and many were recorded as confirmed smokers using primitive pipes with thin wood or stem pipes. The decline in this tumour may be due to a change in smoking methods rather than in the habit.

The infrequency of carcinomas of the tongue, mouth, tonsils, pharynx, and larynx is notable and corresponds with recent experience ; this infrequency would seem to be of long standing in Uganda. The low figures of the Mengo series might be due to diagnosis as out-patients without admission of inoperable cases, but this does not seem likely, as even the few admitted were advanced cases. The incidence of syphilis in Uganda in

*The beginning of this paper appeared last week.

t Department of Murbid Anatomy, Postgraduate Medical Scbool, London. + Makerere College Medical School, Kampala, Uganda

Present address: Albany Modical College of Union University, Albany, New York. these decades has been high, but there does not seem to be any reflection of this in the frequency of tongue, mouth, and cheek or laryngeal cancers.

The infrequency of laryngeal cancers and of lung cancers may be connected with the infrequency of oral, tonsillar, and pharyngeal cancers. Tumours of these sites were diagnosed in Indians and Europeans.

Experience with salivary tumours at Mengo again concords with recent findings, notably in the distribution of mixed salivary tumours and the frequency with which they arise in sites other than the parotid gland. Of the Mengo series the parotid was involved in 16 cases, the submaxillary gland in 6, and the lip and palate in one case each. There were also two tumours of the lacrimal gland, one of which behaved in a malignant fashion in 1906. Lacrimal-gland tumours are to-day relatively much more common in Africans than in Europeans.

\section{Cancer of Sex Organs}

Mengo Hospital experience with cancers of the sex organs is in close conformity with recent findings, as is shown in Table VI, in which neoplasms are given as percentages of all tumours in the appropriate sex. There appears to have been virtually no change over the years as regards the frequency 
of these tumours. Right from the start there was a high frequency of ovarian carcinoma, which obtains to-day, as does the low frequency of breast carcinoma in females. In the Mengo series there were four carcinomas of the male breast to 51 of the female ; in the Kampala Registry 7 male to 113 female, giving the same proportions. There has been an apparent moderate increase in cervix uterus carcinoma, but this is slight and perhaps due to increasing emphasis on

TABLE VI.-Cancers of Sex Organs

\begin{tabular}{|c|c|c|c|}
\hline Site & & Mengo Hospital & Kampala Cancer Registry \\
\hline $\begin{array}{l}\text { Breast }\left\{\begin{array}{l}\text { female } \\
\text { male }\end{array} \quad \ldots\right. \\
\text { Ovary } \\
\text { Cervix uteri } \\
\text { Vulva and vagina } \\
\text { Penis } \quad .\end{array}$ & $\begin{array}{l}\ldots \\
\because \\
\because \\
\cdots\end{array}$ & $\begin{array}{r}10.4 \% \\
0.9 \% \\
11.6 \% \\
22.9 \% \\
2.2 \% \\
14.9 \%\end{array}$ & $\begin{array}{r}9.2 \% \\
0.5 \% \\
8.7 \% \\
24.5 \% \\
3.2 \% \\
12.2 \%\end{array}$ \\
\hline
\end{tabular}

Percentages expressed as percentage of all tumours in the same sex.

gynaecology, and the differences in other tumours are small. Only in respect of testicular tumours is there a difference, and this, over a 60-year span and in ignorance of tribes or addresses, is easily understandable. Testicular tumours are very rare in Africans.

Two instances of sarcoma arising in uterine fibroids are reculded, but the first definite diagnosis of carcinoma of the body of the uterus was made only in the fifth decade. It was probably underdiagnosed and figures in some of the obscure abdominal cancers which are discussed later. A woman with carcinoma of the cervix had previously had a malignant melanoma removed elsewhere, and she provided the only double malignancy in this series.

\section{Gastro-intestinal and Abdominal Cancers}

Uganda does not share the frequency of oesophageal cancer seen in other regions to the south, and again the overall picture in Mengo Hospital concords with current experience. Consideration of the other abdominal and gastro-intestinal cancers does raise difficulty. We have found (Davies and Owor, 1960) that cancerous livers in Africans are primary hepatomas in $90 \%$ of cases. The great frequency of primary liver cancers was not recognized until recent years in Uganda, and it is probable that at all times there was a tendency not to admit obviously inoperable cases with enlarged knobbly livers. From the descriptions typical primary hepatocellular carcinomas were admitted in all decades, but in only 12 do we have notes of the operation findings, and there were five others in which at operation a diagnosis of secondary carcinomatous liver involvement was made without a primary being found. Some may have been cholangiocellular tumours, as they are described as white nodules. The only way of taking the analysis farther seem to be to consider the reliability of diagnosis, and the Table VII.-Comparison of Abdominal Cancers. Mengo Hospital,
1897-1956, and K.C.R., 1952-60

\begin{tabular}{|c|c|c|c|c|c|c|c|c|c|}
\hline \multirow{3}{*}{\multicolumn{2}{|c|}{ Site }} & \multicolumn{5}{|c|}{$\begin{array}{c}\text { Mengo } \\
\text { Hospital }\end{array}$} & \multicolumn{3}{|c|}{$\begin{array}{c}\text { Kampala } \\
\text { Cancer Registry }\end{array}$} \\
\hline & & \multirow{2}{*}{ Total } & \multicolumn{2}{|c|}{$\begin{array}{l}\text { Means of } \\
\text { Diagnosis }\end{array}$} & \multicolumn{2}{|c|}{ Sex } & \multicolumn{2}{|c|}{ Sex } & \multirow{2}{*}{ Total } \\
\hline & & & Oper. & Clin. & $\mathbf{M}$ & $\mathbf{F}$ & $\mathbf{M}$ & $\mathbf{F}$ & \\
\hline $\begin{array}{l}\text { Stomach } \\
\text { Small intestine } \\
\text { Colon .. } \\
\text { Pancreas } \\
\text { Ovary and gall } \\
\text { Liver and } \\
\text { bladder, } \\
\text { Primary } \\
\text { Secondary }\end{array}$ & $\begin{array}{l}\because \\
\because \\
\therefore \\
\\
\therefore\end{array}$ & $\begin{array}{r}42 \\
6 \\
42 \\
17 \\
57 \\
\\
\\
51 \\
25\end{array}$ & $\begin{array}{r}18 \\
6 \\
22 \\
9 \\
43 \\
\\
12 \\
5\end{array}$ & $\begin{array}{r}24 \\
0 \\
20 \\
8 \\
14 \\
\\
\\
39 \\
20\end{array}$ & $\begin{array}{l}22 * \\
4 \\
24 \\
11 \\
- \\
34 \dagger\end{array}$ & $\begin{array}{l}19 * \\
2 \\
18 \\
6 \\
57 \\
\\
14 \dagger \\
16\end{array}$ & $\begin{array}{r}63 \\
3 \\
26 \\
12 \\
\\
174 \\
29\end{array}$ & $\begin{array}{r}27 \\
0 \\
13 \\
7 \\
113 \\
\\
\\
36 \\
15\end{array}$ & $\begin{array}{r}90 \\
3 \\
39 \\
19 \\
113 \\
\\
210 \\
44\end{array}$ \\
\hline Total & . & 240 & 115 & 125 & 104 & 132 & 307 & 211 & 518 \\
\hline
\end{tabular}

- Sex not stated in 1 case. + Sex not stated in 3 cases. sex distribution, for each of the major abdominal tumours (Table VII).

All the cases of carcinoma of the duodenum and small intestine were so diagnosed at operation and may be so ascribed subject to reservations regarding their exact nature, as only two were histologically examined. Of the 17 carcinomas of the pancreas nine were diagnosed operatively and the diagnosis seems well founded; the clinically diagnosed cases were all associated with severe jaundice, an unusual feature in primary hepatocellular carcinoma. Two cases of gall-bladder and bileduct carcinoma were diagnosed operatively and both patients were severely jaundiced. It is notable that over $70 \%$ of the ovarian malignancies were diagnosed at operation, and there seems to have been a reluctance to make this diagnosis without operative support. Nonetheless, if it is reasonable to compare with present-day findings as is done in Tables VII and VIII

TABLE VIII.-Comparison of Main Abdominal Cancers. Mengo Hospital and Kampala Cancer Registry

\begin{tabular}{|c|c|c|c|c|c|}
\hline \multirow{2}{*}{\multicolumn{2}{|c|}{ Site }} & \multicolumn{2}{|c|}{$\begin{array}{l}\text { Abdominal Cancers } \\
\text { Shown in Table VII }\end{array}$} & \multicolumn{2}{|c|}{$\begin{array}{l}\text { All } \\
\text { Cancers }\end{array}$} \\
\hline & & Mengo & K.C.R. & Mengo & K.C.R. \\
\hline $\begin{array}{l}\text { Stomach } \\
\text { Colon } \\
\text { Pancreas } \\
\text { Ovary } \\
\text { Liver, primary } \\
\text { "0 8econdary } \\
\text { ", all }\end{array}$ & $\begin{array}{l}\ddot{ } \\
\ddot{0} \\
\ddot{0} \\
\ddot{.}\end{array}$ & $\begin{array}{l}17.5 \% \\
17.5 \% \\
7.1 \% \\
23.8 \% \\
21.3 \% \\
10.4 \% \\
31.7 \%\end{array}$ & $\begin{array}{r}17.4 \% \\
7.5 \% \\
3.6 \% \\
21.8 \% \\
40.5 \% \\
8.5 \% \\
49.0 \%\end{array}$ & $\begin{array}{l}4.3 \% \\
4.3 \% \\
1.8 \% \\
5.9 \% \\
5.3 \% \\
2.6 \% \\
7.9 \%\end{array}$ & $\begin{array}{l}2.8 \% \\
1.3 \% \\
0.6 \% \\
3.6 \% \\
6.6 \% \\
1.4 \% \\
8.0 \%\end{array}$ \\
\hline
\end{tabular}

it would appear that ovarian carcinoma was diagnosed as frequently as it might be expected to be. The real difficulty arises in considering the sex ratios in Table VII, when it would seem that too many cases of alleged primary liver carcinoma are attributed to females and the proportion of alleged secondary liver cancer is disparate to recent experience. Sources for such misdiagnosis might lie in the overdiagnosis of colonic and gastric malignancy in females or in underdiagnosis of rectal or corpus uterus cancer. Study of the protocols suggests that the clinical diagnosis of gastric cancer in the unoperated cases was reasonable, ${ }^{1}$ and that, for reasons discussed below, this was also the case with colonic cancer. The difficulty would be explained if there was underdiagnosis of rectal cancer, which seems to be more frequent in African females than males, and of corpus uterus cancer, which (Tables IV and V) may well have been the case. Even so, there were eight females to two males with rectal carcinoma.

This may have affected the proportion of rectal to colonic cancer, which in the Mengo series is unlike the present-day proportions. But the Mengo series does show the high frequency of caecal and ascending colon carcinoma which is found in the Kampala Cancer Registry. In 69 colonic cancers collected in Kampala (1948-60) the site was not identified in 7, but $32(46 \%)$ arose in the caecum or ascending colon. In the Mengo series of 42 colonic cancers diagnosed, laparotomy disclosed, in 22 operations, 13 cancers of the caecum and ascending colon and 9 in the rest of the colon. Two more were diagnosed as caecal in origin on clinical grounds. The distribution is specified in only 3 of the 20 cases not operated on. Thus at least $15(36 \%)$ of the 42 colonic cancers were right-sided and probably there were others. The first colonic cancers Cook operated on were in the caecum and ascending colon.

1 Dr. R. T. S. Goodchild has drawn our attention to the close relationship Mengo Hospital enjoyed with various similar if less well equipped mission hospitals in western Uganda and Rwanda-Urundi. The frequency of peptic alceration in the tribesmen of these regions bas been found $w$ be eonsiderably higher than in the Kampala region, and many such cases were transferred for malor abdominal operations. He curgests that this may be a factor in increasing percentages of gastric and colmic cancer above those found in the Kampala Survey. Dr. Goodchild further agrees that primary liver cancers were certainly underdiagnosed. 


\section{Skin Cancer}

Melanomas were found in all decades but one, and in conformity with recent findings they arose almost exclusively on the feet-in 10 of 11 males, and five of seven females. In two females melanomas arose from the hand and in one male from the palate. During this period four melanomas affected the eyes -two apparently extraocular and two intraocularly, the latter being rare tumours in Africans, as none were recorded in the Kampala Cancer Registry.

Squamous carcinomas are recorded in 11 cases (5 male, 6 female) as arising on the legs. Other areas affected were the scalp, chest wall, arms, and scrotum. The paucity of cases arising on tropical ulcers contrasts with present-day experience. These tumours were certainly underdiagnosed both because of confusion with syphilitic ulcers and because of treatment as out-patients, and the development of malignancy is often difficult to recognize both clinically and histologically because many are highly differentiated tumours.

Kaposi sarcoma was first diagnosed in Uganda by Loewenthal in 1938, but the Mengo records contain from the second decade multiple spindle-cell sarcomas or angiomas of the skin of the legs which seem to be cases of Kaposi sarcoma, and, from the description, a pharyngeal nodule removed in the fifth decade was of this nature. Only one doubtful case was seen in a female.

\section{Thyroid Carcinomas}

The sex distribution of thyroid carcinomas in the Mengo records (six female, 1 male) corresponds with present-day Uganda experience, where the proportions were 11 male to 29 female. One of the thyroid tumours occurred in a young boy and was probably lymphomatous in nature, as there were bone lesions. It is a peculiar feature of thyroid cancer in the African that it so often metastasizes to the vault bones of the skull, particularly to the occipital bone, where it is not infrequently mistaken for a very vascular sarcoma. There were six sarcomas of the skull bones or head recorded in the Mengo notes, and it is possible that some of these may have been thyroid carcinomas.

\section{Leukaemias and Myelomas}

Two typical cases of leukaemia, one myeloid and one lymphatic, were diagnosed, with confirmation by blood smears, in the first decade, and, in all, 20 leukaemias and two myelomas were recorded (Table IX), one of the latter being extraosseous. As in all malarious areas, blood-slide examination is mandatory on every sick person, especially a child, and it is unlikely that cases of chronic leukaemia would have been missed. In these 60 years only four cases of leukaemia, all of the lymphatic type,

TABLE IX.-Leukaemias and Myelomas

\begin{tabular}{|c|c|c|c|}
\hline & & Mengo Hospital & Kampala Cancer Registry \\
\hline $\begin{array}{l}\text { Leukaemias } \\
\text { Myelomas } \\
\text { Lymphatic leukaemia } \\
\text { Myeloid } \\
\text { Acute, unclassified }\end{array}$ & $\ddot{x}$ & $\begin{array}{c}20 \quad 2.1 \% \%^{*} \\
20.2 \% \%^{*} \\
35.0 \% \dagger \\
60.0 \% \dagger \\
5.0 \% \dagger\end{array}$ & $\begin{array}{c}104 \quad \begin{array}{l}3.2 \% \\
15 \\
0.5 \%\end{array} \\
41 \cdot 3 \% \%^{*} \\
48.8 \%+ \\
9 \cdot 9 \% \dagger\end{array}$ \\
\hline
\end{tabular}

* Percentage of all cancers. † Percentage of all leukaemias.

were diagnosed in children, which conforms with more recent experience. The percentage of type distribution of leukaemias in the Mengo series-myeloid 60\%, lymphatic 35\%, acute unclassified $5 \%$-is also in line with recent surveys. Two of the lymphatic leukaemia cases, females aged 10 and 30 years, were specifically stated to be "chronic" in type, while seven were described as acute.

\section{Tumours Involving Lymph Nodes}

It has not been easy to attempt classification of the primary lymph-node tumours which are so abundant in Uganda, nor to distinguish primary from secondary carcinomatous involvement in previous years. Of 74 cases of lymph-node involvement, six in the last two decades were found to be due to secondary carcinoma and are so designated. It is more difficult to decide in the earlier decades in the absence of histological records. Recent examination of 419 cases in Kampala of primary lymphnode tumours in adults (Davies, in press) has shown the following distribution-lymphosarcoma $45 \%$, reticulum-cell sarcoma $29 \%$, Hodgkin's disease $24 \%$, and giant follicular lymphoma $1.6 \%$. In the Mengo records there is very frequent mention of the softness and rubbery feeling of the nodes, and we have the impression that most of the 68 cases were primary lymph-node tumours because we think that Cook and his associates did not admit cases with the usual hard shotty glands of secondary carcinoma. Of the 68 cases 55 were in adults and $36 \%$ (18 male, 2 female) were diagnosed as Hodgkin's disease with histological confirmation in 12 cases; one other was diagnosed on biopsy as a giant follicular lymphoma, and the nature of the remainder is uncertain, another four only being biopsied. Of the children three were diagnosed as cases of Hodgkin's disease.

\section{Tumours of the Bone, Jaw, Eye, and Orbit}

Retrospective diagnosis of the tumours of these sites was difficult and is indeed impossible save in the light of recent findings. Thus the peculiar manifestations of the curious malignant lymphoma of children in Africa was not recognized prior to 1958 (Burkitt, 1958; Davies and Davies, 1960 ; O'Connor and Davies, 1960) and the strange pattern of organ involvement not appreciated. Lymphoma is by far the commonest, indeed almost the only, jaw tumour of young children in Uganda, and such jaw tumours are rare after 15 years of age though adult cases do exist (Lurie and King, 1962). Davies and Davies (1960) found no cases of adamantinoma under the age of 15, and among 32 adult cases the maxilla was involved in only four cases. In the Mengo records it is clear that in the early years adamantinomas and osteoclastomas were often confused.

A further difficulty is the frequency with which jaw lymphomas involving the maxillae invade the orbits, causing protrusion and destruction of the eyeballs. Moreover, orbital tumours in African children are distributed between lymphomas, retinoblastomas, and rhabdomyosarcomas, the last group being much less common, and distinction between them is often a major histological puzzle. In Table $\mathrm{X}$ the bone, jaw, eye, and orbital tumours are shown by age and sex, and the predominance of jaw tumours above the tumours of all the other long bones is obvious. Well did Cook remark that jaw tumours

TABlE X.-Mengo Hospital. Bone, faw, Eye, and Orbit Tumours

\begin{tabular}{|c|c|c|c|c|c|c|c|}
\hline \multirow{2}{*}{ Site } & \multicolumn{2}{|c|}{ Adults } & \multicolumn{2}{|c|}{ Children } & \multirow{2}{*}{$\begin{array}{l}\text { Adult } \\
\text { Total }\end{array}$} & \multirow{2}{*}{$\begin{array}{c}\text { Child- } \\
\text { ren } \\
\text { Total }\end{array}$} & \multirow{2}{*}{ Total } \\
\hline & $M$ & $\mathrm{~F}$ & $\mathbf{M}$ & F & & & \\
\hline $\begin{array}{ll}\text { Jaw bones } & \ldots \\
\text { Other ," } & \cdots \\
\text { Eye/orbit } & \ldots\end{array}$ & $\begin{array}{l}38 \\
23 \\
14 \\
\end{array}$ & $\begin{array}{r}21 \\
12 \\
6\end{array}$ & $\begin{array}{r}13 \\
3 \\
5\end{array}$ & $\begin{array}{r}11 \\
2 \\
7\end{array}$ & $\begin{array}{l}59 \\
37 * \\
21 \dagger\end{array}$ & $\begin{array}{r}24 \\
5 \\
12\end{array}$ & $\begin{array}{l}83 \\
42 * \\
33\end{array}$ \\
\hline Total ... & 75 & 39 & 21 & 20 & $117^{*}$ & 41 & $158^{*}$ \\
\hline
\end{tabular}

were particularly common. The location of jaw tumours is shown in Table XI, and the locations of the jaw tumours in children adds up to more than the total of cases, reflecting the difficulty of deciding on the focus of origin of a massive jaw tumour (see Appendix, first case) as well as the known multicentricity of jaw lymphomas in children (for illustrations see Burkitt, 1962). 
In adults it would seem probable that the majority of the tumours of the lower jaw were adamantinomas from the descriptions. The upper-jaw tumours are more difficult to diagnose and the orbital tumours in adults are impossible to disentangle. Three of the maxillary tumours were regarded as carcinomas of the antrum, and probably others were of this nature, but from the description, backed in some cases by

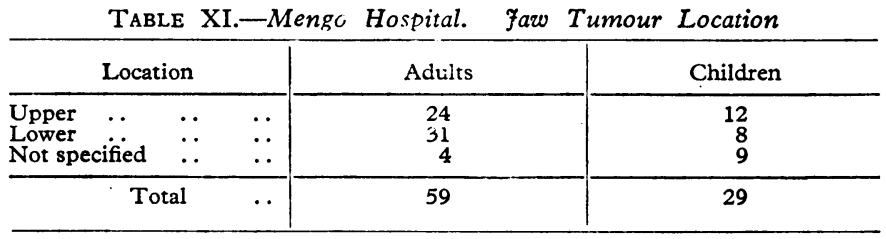

histology, many appear to have been sarcomas, while others were clearly osteofibromas. Of the adult eye/orbit tumours fir were diagnosed as ocular carcinomas, tumours common in Uganda to-day ; the others were diagnosed as sarcomas. The jaw tumours in children are discussed below; most if not all were lymphomas.

It is evident, however, that the high frequency of jaw tumours so notable in Uganda to-day both in adults and in children has been a feature of the tumour pattern there since 1897 and is not of recent development.

The distribution of tumours in bones other than the jaw is shown in Table XII. The nature of most of these is unascertainable, but from the descriptions all appear to have been true tumours. Five were osteosarcomas histologically and four were giant-cell tumours. Of the five children with non-jaw bone tumours three had lesions elsewhere-for example, thyroidsuggesting that they may have been lymphomatous.

TABLE XII.-Mengo Hospital. Tumours in Bones Other than the faw \begin{tabular}{lll|lll|lll|lll} 
Femur &. & 7 & Skull &. & 5 & Foot &. & 1 & Clavicle &. & 1 \\
Tibia & $\because$ & 9 & Rib &. & 2 & Ulna & $\because$ & 1 & Sacrum & 0 & 2 \\
Humerus & 5 & Hand &.. & 2 & Radius &.. & 1 & Unspecified & 1
\end{tabular}

\section{Soft-tissue Sarcomas}

Histology is available on only nine of the cases diagnosed as having soft-tissue sarcomas; two were desmoids, two fibrosarcomas, and the others were sarcomas of various sorts-lipo-, myxo-, angio-, etc. The site of origin of the soft-tissue sarcomas in adults is shown in Table XIII.

TABLE XIII.-Mengo Hospital. Soft-tissue Sarcoma-Adults

\begin{tabular}{|c|c|c|c|c|c|}
\hline \multicolumn{4}{|c|}{ Abdominal wall desmoids } & & \\
\hline So & tiss & thigh & .. & . & 4 \\
\hline " & " & shoulder & 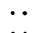 & $\cdot$ & $\begin{array}{l}2 \\
2\end{array}$ \\
\hline " & " & spine & $\cdots$ & $\cdot$ & 2 \\
\hline " & " & arm & $\cdots$ & $\cdot$ & 2 \\
\hline$"$ & " & grom & $\cdots$ & $\cdot$ & 2 \\
\hline
\end{tabular}

$$
\begin{aligned}
& \text { Soft tissue, neck } \\
& \text { ", buttock } \\
& \text { Angiosarcoma, head } \\
& \text { Chondrosarcoma, nose } \\
& \text { Not specified .. } \\
& \text { Retroperitoneum }
\end{aligned}
$$

\section{Tumours of Children in Mengo Hospital}

Children have been taken as those 15 years of age and under, and in six decades 89 were admitted, the percentage of children with cancer showing only a slight fall (Table II). The site involvement is shown in Table XIV; the overwhelming preponderance of jaw and eye/orbit tumours, making up over one-third of the total, is obvious. In view of current findings that African lymphoma is responsible for one-half of the childhood malignancies in Uganda and that in half of such cases

TABLE XIV.-Neoplasms of Children. Mengo Hospital, 1897-1956

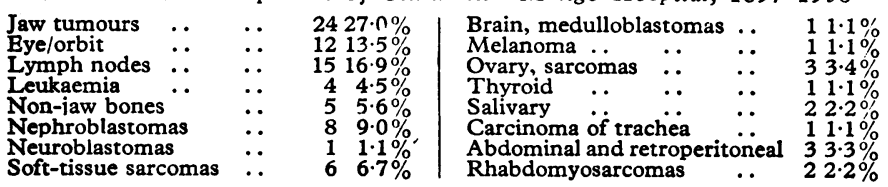

the jaws are involved, it is possible to make some sense of Table XIV. Indeed, only 21 cases included in the series can be said definitely not to be lymphoma. All save one of the jaw tumours appear lymphomatous, the three ovarian sarcomas are from the descriptions clearly lymphomas, and the thyroid, abdominal, and retroperitoneal tumours are probably lymphomas; so probably are some of the soft-tissue sarcomas, non-jaw bone tumours, and the lymph-node tumours. If the 23 jaw tumours were lymphomatous we would expect there to be 23 non-jaw lymphomatous cases-a total of 46 , which is about $50 \%$ of 89 cases that we would expect on current experience. There is such close correspondence in the other tumours (O'Conor and Davies, 1960) that this seems not unreasonable-for example, Mengo leukaemia $4.5 \%$, K.C.R. $5.6 \%$, nephroblastomas 9 and $10 \%$, gliomas 1.1 and $1.2 \%$.

The diagnosis by age for the principal types is shown in Table XV and by decades in Table XVI. The latter shows how the frequency of jaw tumours in children goes back to the first decade of Mengo Hospital's work, and therefore it seems

\begin{tabular}{|c|c|c|c|c|}
\hline & & $0-4$ Years & 5-10 Years & $11-15$ Years \\
\hline $\begin{array}{l}\text { Jaw tumours } \\
\text { Eye/orbit } \\
\text { Lymph nodes }\end{array}$ & $\begin{array}{l}\ddot{ } \quad \cdots \\
\ddot{*} \quad\end{array}$ & $\begin{array}{l}2 \\
2 \\
0\end{array}$ & $\begin{array}{r}13 \\
2 \\
6\end{array}$ & $\begin{array}{l}1 \\
2 \\
5\end{array}$ \\
\hline
\end{tabular}
legitimate to conclude that there has been little change in the pattern of children's cancer in Uganda over six decades and that the curious lymphoma of childhood has been occurring

\begin{tabular}{|c|c|c|c|c|c|c|}
\hline & $\begin{array}{c}1897- \\
1906\end{array}$ & $\begin{array}{c}1907- \\
16\end{array}$ & $\begin{array}{c}1917- \\
26\end{array}$ & $\begin{array}{c}1927- \\
36\end{array}$ & $\begin{array}{c}1937- \\
46\end{array}$ & $\begin{array}{c}1947- \\
56\end{array}$ \\
\hline $\begin{array}{ll}\text { Jaw tumours } & \ldots \\
\text { Eye/orbit } & \ldots \\
\text { Nephroblastoma } & \ldots \\
\text { Lymph nodes } \\
\text { Total No. with }\end{array}$ & $\begin{array}{l}3 \\
0 \\
0 \\
\mathbf{0} \\
\mathbf{5}\end{array}$ & $\begin{array}{r}4 \\
5 \\
2 \\
0 \\
15\end{array}$ & $\begin{array}{r}5 \\
1 \\
0 \\
6 \\
18\end{array}$ & $\begin{array}{r}4 \\
1 \\
1 \\
4 \\
15\end{array}$ & $\begin{array}{r}5 \\
2 \\
1 \\
2 \\
15\end{array}$ & $\begin{array}{r}3 \\
3 \\
4 \\
3 \\
21\end{array}$ \\
\hline
\end{tabular}
in Uganda for the last 60 years.

TABLE XV.-Age Distribution. Principal Children's Tumours

TABLE XVI.-Mengo Hospital. Distribution of Children's Neoplasms by Decades

\section{Asian and European Cancer at Mengo Hospital}

Members of both these communities in Uganda have tended, especially in former years, to retreat to their homelands for major operations or for radiotherapy, which is not available in Uganda. Moreover, many are officials and with their families are entitled to treatment in Government hospitals. In the early decades they were predominantly male communities, and European women and children were few in Uganda prior to 1939 save for missionary families, nursing sisters, and teachers. Indeed, no European child with cancer was ever admitted to Mengo Hospital. Asians, particularly women, are reluctant to submit to diagnostic procedures or to surgery. Cancer incidence rates in these communities rise steadily with age. The main importance of the few cases in the Mengo series is the fact that Cook and his associates were seeing in these communities tumours-for example, laryngeal cancer, lung and intracranial growths-they rarely diagnosed in Africans. Tables XVII and XVIII show the cancers in these communities and the numbers seen in the six decades. They show the cancer distributions which would be expected, the high frequency of female breast cancer in Europeans being notable.

Even in these small series there are some odd features. One is that among seven colonic cancers (five Asian, two European)

TABLE XVII.-Mengo Hospital. European and Asian Cancers

\begin{tabular}{ll|c|c|c|c|c|c|c}
\hline & & $1897-$ & $1907-$ & $1917-$ & $1927-$ & $1937-$ & $1947-$ & Total \\
& 1906 & 16 & 26 & 36 & 46 & 56 & \\
\hline $\begin{array}{ll}\text { Asian } \\
\text { European }\end{array}$ & 0 & 0 & 1 & 10 & 12 & 17 & 31 & 71 \\
\hline
\end{tabular}


there were four carcinomas of the caecum (three Asian, one European), rather like what has been found in the African. Another is that three of the nine Asian children with cancer presented with jaw sarcoma, in two the mandible being affected; and all appear from the descriptions, and in one from the histology, to have been of the African lymphoma type. The first two were seen in 1917 and 1926.

TABLE XVIII.-Mengo Hospital, 1897-1956. Asian and European

\begin{tabular}{|c|c|c|c|c|c|c|c|c|}
\hline \multicolumn{9}{|c|}{ Cancers } \\
\hline \multirow{2}{*}{\multicolumn{3}{|c|}{ Site }} & \multicolumn{3}{|c|}{ Asian } & \multicolumn{3}{|c|}{ European } \\
\hline & & & $\mathbf{M}$ & $\mathbf{F}$ & Total & $\mathbf{M}$ & $\mathbf{F}$ & Total \\
\hline $\begin{array}{l}\text { Lip } \\
\text { Tongue . } \\
\text { Salivary } \\
\text { Mouth ... } \\
\text { Tonsil . } \\
\text { Oesophagus } \\
\text { Stomach } \\
\text { Colon .. } \\
\text { Rectum } \\
\text { Anus .. } \\
\text { Liver and gall- } \\
\text { Primary } \\
\text { Secondary } \\
\text { Pancreas } \\
\text { Nose/sinus } \\
\text { Larynx } \\
\text { Lung ... } \\
\text { Breast .. } \\
\text { Cervix uterus } \\
\text { Body uterus } \\
\text { Ovary ... } \\
\text { Kidney } \\
\text { Bladder } \\
\text { Skin, squamou } \\
\text { rodent } \\
\text { Bye/orbit } \\
\text { Intracranial } \\
\text { Thyroid } \\
\text { Bones ... } \\
\text { Soft tissue } \\
\text { Lymph nodes } \\
\text { Leukaemia } \\
\text { Myeloma } \\
\text { Jaw bones } \\
\text { Malignant tera } \\
\text { Unspecified }\end{array}$ & 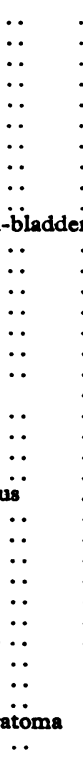 & 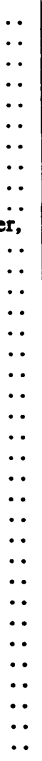 & $\begin{array}{l}3 \\
1 \\
4 \\
1 \\
0 \\
0 \\
0 \\
0 \\
0 \\
0 \\
0 \\
1 \\
0 \\
1 \\
1 \\
2 \\
2 \\
2 \\
3 \\
0 \\
3 \\
0 \\
1\end{array}$ & $\begin{array}{l}0 \\
0 \\
0 \\
1 \\
6 \\
3 \\
1 \\
1 \\
0 \\
0 \\
0 \\
0 \\
0 \\
1 \\
1 \\
1 \\
0 \\
1 \\
1 \\
0 \\
0 \\
0 \\
2\end{array}$ & $\begin{array}{r}1 \\
1 \\
1 \\
1 \\
1 \\
1 \\
1 \\
5 \\
4 \\
1 \\
10 \\
3 \\
1 \\
4 \\
2 \\
6 \\
3 \\
1 \\
1 \\
0 \\
0 \\
0 \\
1 \\
0 \\
2 \\
2 \\
3 \\
2 \\
3 \\
4 \\
0 \\
3 \\
0 \\
3\end{array}$ & $\begin{array}{l}0 \\
0 \\
0 \\
2 \\
1 \\
0 \\
0 \\
0 \\
1 \\
1 \\
1 \\
1 \\
1 \\
0 \\
0 \\
0 \\
1 \\
3 \\
0 \\
2 \\
0 \\
1 \\
0\end{array}$ & $\begin{array}{l}0 \\
0 \\
0 \\
0 \\
9 \\
2 \\
0 \\
2 \\
0 \\
0 \\
0 \\
0 \\
0 \\
0 \\
0 \\
0 \\
1 \\
0 \\
0 \\
0 \\
0 \\
0 \\
0 \\
0\end{array}$ & $\begin{array}{r}0 \\
0 \\
0 \\
2 \\
10 \\
2 \\
0 \\
2 \\
1 \\
1 \\
1 \\
1 \\
1 \\
0 \\
0 \\
0 \\
2 \\
3 \\
0 \\
2 \\
0 \\
1 \\
0\end{array}$ \\
\hline Total & & 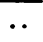 & 49 & 22 & 71 & 23 & 16 & 39 \\
\hline
\end{tabular}

\section{General Discussion}

From its foundation Mengo Hospital has been staffed by highly qualified and trained personnel whose careful, patient recording of case notes is the foundation of this study. Neither in the remarks above nor in this discussion is any criticism implied or intended of these men and women whose high idealism and devoted service we deeply admire. The senior authors are sufficiently aware of their own errors and omissions to be critical of men and women who worked to the best of their ability often in circumstances of great difficulty. The Mengo Hospital records have been analysed to try to answer two questions. How common was cancer in the past ? and Were the varieties of cancers the same as we have recorded in recent years ? The study starts at a time when everything imported into Uganda was carried by headload and when the first doctor to study and treat disease in the African population had walked the great distance from the coast. It began in reed huts. It ended in days of concrete and chromium, of radioisotopes and autoanalysers brought in by modern railways or jet aircraft. Our study covers a period from almost the Iron Age to Rocketry. With the opening of the railway in 1902 Uganda's isolation ended, the prices of imported goods dropped, motor-cars appeared, and with the development of cotton and other cash crops wealth was spread, if only very thinly, among the ordinary people until to-day Uganda by African standards is a prosperous country importing food, clothes, and other manufactured goods. But Uganda still remains a country of subsistence farming with virtually no industrialization.

How has this affected the cancer situation? While wishing to analyse the situation as it was in the past we have found a pattern of cancer so different from that of other countries that it is only understandable in terms of the pattern revealed by studies in the last decade. We have found that the ratio of cancers to total admissions at Mengo Hospital has remained remarkably stable over six decades. The ratios are low, as low as those which in the past were used to support the idea that cancer was a rare disease of " primitive peoples." Yet out of such ratios in recent years it has been possible to construct incidence rates based on annual registrations which in the younger age-groups are comparable with those of Norway.

In most instances where site and type comparisons are possible we have found that the pattern of site and type involvement is similar, that melanomas predominantly arise on the feet, that colonic cancers are often on the right side, that submaxillary-gland and lacrimal-gland tumours are unduly frequent, that children have had lesions of unusual sites comparable to those found to-day, and that jaw tumours both in children and in adults have been unduly frequent for 60 years. The anomalies are usually minor and susceptible of explanation. Only in one case, lip cancer, does there seem to have been a decline, and this is linked with a change which has been appreciated. Penile tumours have always been common.

The impression is that the tumours Cook saw commonly in the first decade are, save lip cancer, the common tumours of Uganda to-day, and it would seem legitimate to conclude that cancer has over this period been as common as it now is, affecting the same sites and appearing in the same varieties. If this is so it would follow that the peculiar aetiological factors which cause such a particular pattern of cancer have been in operation over a period much longer than the six decades covered by the Mengo Hospital records. The causative factors are truly indigenous and embedded in the way of life of the ordinary Uganda African and have not been materially altered over the last six decades.

The stability of the admission rates and the constancy of the pattern would seem to negate the suggestion, unacceptable on other grounds, that the cancer incidence rate falls off in the older age-groups because of the premature death of those who, if they had survived, would have developed cancer. Removal or diminution in many of the lethal diseases of previous years has not altered the pattern. The children's tumours have remained constant over the decades in their pattern and in their frequency. Errors of diagnosis cannot explain this, and over a 60-year period of constantly improving standards of diagnosis these have not brought to light a greater proportion of, say, leukaemias than were diagnosed at Mengo Hospital. The nature and the behaviour of the tumours diagnosed in earlier years have become clearer in modern times, but they were present from the earliest days.

We conclude, then, that from the first days of modern medicine in Uganda, and for over 60 years, cancer has been as common as it is to-day and is of the same distribution as it has always been. There is and never has been any warrant for believing that a low ratio of cancers to total admissions indicates any infrequency of cancer in a "primitive" community, and we regret that the long controversy on the point has obscured the really important and perhaps vital question. This is the reason for the very different cancer patterns of different communities.

\section{Summary}

On the basis of a low ratio of cancer cases to total hospital admissions some have held cancer to be uncommon in underdeveloped tropical countries. In Uganda, East Africa, medical records since 1897 are available at the Mengo Mission Hospital, and these have been analysed and compared with the findings in recent surveys in Uganda. At Mengo Hospital the ratio of cancer to total admissions has remained fairly steady over a 60 -year period that has seen the country develop from a region where everything was imported by headload to a country with an advanced system of communications. 
There has also been a very constant pattern of cancer over the six decades as regards site and type. This pattern differs considerably from the European pattern in the infrequency of certain types of cancer and the undue frequency of others. This analysis could not have been interpreted in terms of cancer in Western countries, and it is only modern knowledge of the Uganda cancer pattern which enables comparisons to be made. This is particularly the case with the common lymphomatous tumour of children, which has evidently been commonly seen in Uganda for the last 60 years.

There is no evidence that cancer has been uncommon in Uganda since the first days of modern Western medicine, and the stability of the site and type-pattern suggests that it is due to factors embedded in the Uganda African way of life.

This investigation has only been $F$ :ssible because of a very generous research grant made availabie to us over several years by the Trustees of the Anna Fuller Fund. It is a pleasure to acknowledge the constant sympathy and interest of Dr. William Gardner in this and many other cancer problems of the African continent. The Mengo records were most generously made available to us by the authorities at Mengo Hospital and by the kindness of the Superintendent, Dr. W. R. Billington. We are grateful to medical students at Makerere College Medical School for their faithful copying of hundreds of case notes. Mr. R. T. S. Goodchild, Professor J. Knowelden, and Dr. W. R. Doll have assisted us on a number of points. The two London workers are in receipt of a grant from the Medical Research Council of Great Britain.
REFERENCES

Berglas, A. (1957). Cancer: Nature, Cause and Cure. Institut Pasteur. Paris.

Burkitt, D. P. (1958). Brit. F. Surg., 46, 218.

(1962). Postgrad. med. 7., 38, 71.

Cook, A. R. (1901). 7. trop Med. Hyg., 4, 175

- (1946). Uganda Memories. Uganda Society, Kampala.

Davies, A. G. M., and Davies, J. N. P. (1960). Acta Un. int. Cancr., 16, 1320.

Davies, J. N. P. (1956). Bull. Wld Hlth Org., 15, 1041

- (1959). Med. Hist., 3, 47.

— and Owor, R. (1960). E. Afr. med. 7., 37, 249.

- Wilson, B. A., and Knowelden, J. (1962). Lancet, 2, 328.

des Ligneris, M. J. A. (1927). 7. med. Ass. S. Afr., 25, 102 (1936). S. Afr. med. F., 10, 478.

Dodge, O. G. (1962). Acta Un. int. Cancr., 18, 548.

Goodchild, R. T. S. (1947). Brit. med. F., 2, 342.

Higginson, J., and Oettlé, A. G. (1960). 7. Nat. Cancer Inst., 24, 589.

Hoffman, F. L. (1915). Mortality of Cancer Throughout the World. A.M.A. Commemoration Volume, Chicago.

Lambkin, F. J. (1908). In A System of Syphilis, edited by D'A. Power and K. Murphy, vol. 2, p. 329. Longman, London.

Leys, N. (1924). Kenya. 3rd ed. Hogarth Press, London.

Lurie, H. I., and King, B. A. (1962). F. Path. Bact., 83, 576.

Moffat, R. U. (1901). 7. trop. Med. Hyg., 4, 326.

Moorehead, A. (1960). The White Nile. Hamish Hamilton, London.

Nedoon, G. S., and Semambo, Y. B. (1956). E. Afr. med. 7., 33, 189.

O'Conor, G. T., and Davies, J. N. P. (1960). \$. Pediat., 56, 526.

Pederven, E. (1961). Cancer Registration in Norway: The Incidence of Cancer in Norway, 1953-8. Norwegian Cancer Society, Oslo.

Roscoe, J. (1921). Twenty-five Years in East Africa. Cambridg= Univ. Press.

Willis, R. A. (1960). Pathology of Tumours, 3rd ed. Butterworth, London.

\title{
Routine Radiography for Haemoptysis
}

\author{
GRAHAM POOLE, $*$ M.B., M.R.C.P. ; PETER STRADLING, $†$ M.D., M.R.C.P.
}

Because of its potentially serious significance a history of haemoptysis is an important reason for general practitioners referring patients for chest radiography. Many with this symptom attend " $x$-ray only" sessions and a proportion prove to have abnormal radiographs leading to immediate recall for investigation. A particular problem is posed, however, by that group in which radiographs are normal. Should this one $\boldsymbol{x}$-ray examination suffice? Should such patients have a precautionary repeat radiograph after an interval ? Should they, perhaps, all be more fully investigated ?

For some years it has been the routine of this unit to take the middle course of repeating radiography after an interval of one month in cases where the initial radiograph was negative. It is known that this is the practice at a number of other clinics. It was thought a reasonable procedure because (a) a small lesion might be missed at the first reading, or $(b)$ an early pathological process (particularly carcinoma), being invisible on the first radiograph, might become apparent after the interval. The second reason was thought the more important because observer variation was reduced so far as possible by the double-reading technique employed (Stradling and Johnston, 1955).

Since this routine had been based on an arbitrary decision it was thought desirable to review a sample of such cases to

\footnotetext{
* Assistant Physician and Tutor in Thoracic Medicine, from the Hammersmith Chest Clinic and Department of Medicine, Postgraduate Medical School of London.

† Physician and Lecturer in Respiratory Diseases, from the Hammersmith Chest Clinic and Department of Medicine, Postgraduate Medical School of London.
}

discover what had actually happened to the patients concerned, and, in the light of the findings, to make any appropriate adjustments in the administrative routine of the " $x$-ray only" service to practitioners.

\section{Method}

All patients referred with haemoptysis during 1960 to the " $x$-ray only" session (using a 100-mm. photofluorographic unit) were included in the first part of the survey (first series). Haemoptysis in this context can be defined only in relation to the history provided, and all patients whose referring letter contained such statements as "blood in the sputum" or " coughing up blood" or "haemoptysis" were accepted for the first series, which then totalled 138.

All records of these patients were closely scrutinized. Where a definite diagnosis, adequate to explain the haemoptysis, had been made in relation to the first attendance (group A) no further special follow-up was carried out for the purpose of this investigation. The second category (group B) consisted of patients whose radiographs were negative both initially and on repeat one month later, and who therefore had been discharged: these patients were followed up by a simple questionary during 1963. The majority answered, but where no response was obtained a further follow-up was conducted by a nurse from the clinic visiting the home, seeking information from the doctor originaliy referring the patient, and, finally, by inquiry through the local executive council. A separate, 